\title{
World Bank's 2012 Ganges Strategic Basin Assessment: A View from Nepal
}

\section{S.B. Pun}

Abstract: The World Bank's 2012 Ganges Strategic Basin Assessment (GSBA) is an interesting but contentious document with a wealth of information. The basin has a population of 656 million; and 47 percent of Indians, 576 million, live in this basin. Nepal's three bordering States of Uttar Pradesh, Bihar and West Bengal with a population of 199, 104 and 91 million respectively have a staggering combined population of 385 million, far greater than that of the USA. The Ganges basin has the world's highest population density and, as a consequence, poverty level borders that of Sub-Sahara. This is India's Hindu cow belt where water is increasingly getting scarce.

With the strategic resource, water, getting scarce in the Ganges, the Bank's GSBA has some startling findings: storages in Nepal store 'significantly little' water, so flood control in India is 'very limited'. Storages in Nepal can 'double lean season flows', but agricultural productivity in India is 'currently very low' from such augmented flows. The Bank believes that 'hydropower and trade' is 'significant' and negotiation 'simpler than previously thought'. The Bank recommends that Nepal push her hydropower development on a fast track. Many believe it is not the 'significant' power trade that counts. What really counts is whether or not the traded Energy will be at a Significant Rate. By pushing Nepal's significant hydropower, the Bank is advocating a policy whereby India avail free lean season water stored in Nepal's fertile valleys submerged for perpetuity. In the Bank's opinion, as India's agricultural productivity is currently very low and flood control very limited, Nepal's downstream benefits are also very low. Nepal is, thus, very disappointed with the Bank's such Indo-centric GSBA report.

Key words: Ganges Strategic Basin Assessment (GSBA), World Bank, treaty, Nepal

\section{Foreword}

The Claudia Sadoff/Nagaraja Rao Harshadeepled 2012 World Bank's 143 page Ganges Basin Strategic Assessment (GBSA) report has, to be fair, created an interesting 'knowledge base' that is 'envisaged to encourage, rather than conclude, debate' on the trans-boundary management issues of the Ganges. The Bank acknowledges it has utilized the inputs and information provided by various Institutes of India, Bangladesh and Nepal' ${ }^{1}$. While the key SWAT model for the Ganges basin was developed in Delhi at the Indian Institute of Technology, the calibrated Ganges Basin Model $^{2}$ was developed in Dhaka by the Institute for Water Management (IWM). Except for IWM and CEGIS of Bangladesh and Nepal's ICIMOD (if it could be called Nepal's), inputs were predominantly from Indian Institutes. Inputs from India were a necessity as the major portion of the Ganga basin is in India. But this did not necessarily mean that the Bank, professing to be 'an honest broker', should reflect biased Indian perceptions. If the Bank did concur with Indian views, it had the liberty to also reflect the other side of the coin of her other two ${ }^{3}$ Ganges riparians, Bangladesh and Nepal. As far as the Ganges is concerned, geography has placed India in an uncomfortable position. But India, with two centuries of colonial British tutoring, has managed extremely well. While India, as the lower riparian to Nepal, wriggled out the 'without prejudice to their respective existing consumptive uses' rights on the Mahakali river, she stuck to her guns on the Farakka by not conceding the historic use rights' claim of her lower riparian, Bangladesh. This article attempts to reflect some of those Nepalese perceptions on the Bank's Indo-centric GBSA report.

\section{Exclusion of Tibet from Ganges Basin Assessment}

According to Dr. K. L. Rao's India's Water Wealth,
$79 \%$ of the Ganga basin is in India, $13 \%$ in Nepal, $4 \%$ in Bangladesh and $4 \%$ in China's Tibet. But the multilateral Bank, whether by accident or design, has conveniently left out the population of Tibet which agreeably is tiny. The Ganges tributaries of the Karnali, Bhote Kosi and Arun in particular have a sizable basin in Tibet. This exclusion is puzzling because it was the very Bank that, as per its much-used OP 7.50 manual, notified ${ }^{4}$ the upper riparian China when Nepal was wrestling with the run-of-river non-consumptive 201 MW Arun III Hydroelectric Project in the early 1990 .

\section{Inclusion of Kalapani as Indian Territory}

Interestingly, a close look on page 20 of the Bank's report showing the Ganges River Basin map indicates Nepal's Kalapani territory as being within India. The Mahakali River in the Himalayas is the border between Nepal and India. The Kalapani area, clearly shown in the map as being east of the Mahakali River, belongs to Nepal. But surprisingly the multilateral institution that is supposed to represent Nepal's interest as well has again, by design or accident, defaulted.

\section{No Basin wide or Multilateral Treaties}

In the last six decades, India has consistently pursued her bilateral policy on the Ganges, from the 1954 Kosi to the 1996 Mahakali and Farakka treaties. The raison d'etre for this is very simple. India used this bilateralism tool to achieve her objectives from both Nepal and Bangladesh, a lower riparian to one but upper riparian to another. It was in such a context that the 'bullied' Bangladesh and Nepal requested India for a regional approach on the Ganges water resources development. But India interpreted $^{5}$ this as 'a gang up of sorts' by Bangladesh and Nepal against her. Now that her eyes have moved on to the larger Brahmaputra waters and now that she is a lower riparian to a large China, it will be interesting 
to see whether India will continue to sing bilateralism or change her tune to regionalism.

The Bank has rightly pointed out 'Until now, there has been no basin wide knowledge base ..... to explore options and facilitate cooperative planning in the Ganges. Information and data are surprisingly scarce and difficult to obtain. In particular, very little information is available on hydrology and irrigation withdrawals in India.' In fact, the Government of India is so secretive about hydrological data that even her own citizen, BG Verghese, puts on record ${ }^{6}$ that India has been 'needlessly paranoid about classifying water resource data.'

\section{On the Ganges Basin Bilateral Treaties}

The following are the four Ganges Basin bilateral treaties, three Indo-Nepal and one Indo-Bangladesh, so far concluded. The following are the World Bank's perceptions in its own words and the view from Nepal on those four Ganges Basin treaties:

\section{i) 1954 Kosi Treaty, Revised 1966}

World Bank's GSBA View: The first treaty, on the Kosi River, was signed between India and Nepal in 1954. The treaty was developed to attenuate routine devastating floods in the Indian state of Bihar. Soon after its conclusion in 1954, however, the treaty came under criticism in Nepal where it was perceived as inequitable, in part because it called for the construction of embankments to contain the course of the Kosi, as well as the construction of the Kosi Barrage, both of which are entirely within Nepal. The land associated with the embankments and barrage (the built and inundated areas) was to be acquired by Nepal and then ceded to India. The Kosi Treaty was amended in 1966 so that the land would be leased to India rather than ceded, but many still felt the terms of that lease (199 years at a nominal annual rate) were inequitable and that it did not properly compensate the loss of fertile farmland in Nepal.

View from Nepal: The Bank states "The treaty was developed to attenuate routine devastating floods in the Indian state of Bihar." The Bank mis-states the Treaty's very preamble "......for the purpose of flood control, irrigation, generation of hydro-electric power and prevention of erosion in Nepal...." So the Kosi treaty is not, as the Bank insinuates, for flood control alone. The Bank astutely refrains from mentioning that the Kosi Barrage irrigates a massive $9,69,100 \mathrm{ha}^{7}$ of land in Bihar while $\mathrm{Nepal}^{8}$ gets a mere 11,300 ha through gravity flow from the western canal. The Bank does indicate that the Kosi Barrage and its associated embankments are all "entirely within Nepal". If one were to believe the scintillating logic of an Indian diplomat ${ }^{9}$, this construction within Nepal was done solely for the purpose of providing irrigation benefits for Nepal; otherwise India could have built the Barrage downstream in her own territories. The Bank rightly mentions that the revised (not amended) 1966 Kosi Treaty leased, rather than ceded, the project land to India and many Nepalese felt the terms of the lease, 199 years at a nominal annual rate, were inequitable. The Bank has studiously failed to mention the 1966 Letters of Exchange that unequivocally stipulates '...that the Government of India will be reasonably compensated in case the Project properties are taken over by His Majesty's Government at the end of the lease period....' India, despite all her professed goodwill towards Nepal, had no bad conscience in demanding 'reasonable compensation' from Nepal after using the Project facilities for 199 years!

\section{ii) 1959 Gandak Treaty, Amended 1964}

World Bank's GSBA View: The second treaty between India and Nepal, the Gandaki Treaty, was signed in 1959 with a focus on flood control, irrigation, and power. The Gandaki River, like the Kosi, brought annual floods that damaged crops and property in both Nepal and India. This treaty is considered more favorable to Nepal than the Kosi Treaty. Nevertheless, it, too, was met with strong objection in Nepal. Unlike the Kosi Treaty, the Gandaki Treaty has not been amended.

View from Nepal: To err is human, and the Bank badly erred in stating that the Gandak treaty has 'not been amended'. The 1959 Gandak treaty was amended in 1964, two years earlier than the older Kosi Treaty. A perusal of the 1959 Gandak Treaty preamble states '.... For the purposes of irrigation and development of power for Nepal and India....' The preamble does not mention 'flood control' but the Bank, in its esteemed opinion, deemed it necessary so that all its sundry readers will also mouth those words. In the Bank's exalted opinion that the Gandak treaty is 'more favorable to Nepal than the Kosi Treaty.' This, unfortunately, is not the case at all. If one peruses Clause 9 of the 1959 Gandak treaty, so conveniently entitled 'Protection of Nepal's Riparian Rights', it stipulates 'His Majesty's Government will continue to have the right to withdraw for irrigation or any other purpose from the river or its tributaries in Nepal ... His Majesty's Government agree that they shall not exercise this right in such manner ... prejudicially to affect the water requirements of the Project as set out in the schedule annexed hereto. This 'without prejudiced to the schedule annexed hereto' was, in fact, protection of India's riparian rights and not Nepal's. Nepal would have no right to withdraw Gandak waters in her own territory upstream if it prejudicially affects India's Schedule of Water Requirements. India, in the annexed Schedule, allotted herself the entire flows (that of dry season) of the Gandak river for her use in the densely populated States of Bihar and UP. It was this very Clause 9 that was deleted in the 1964 amendment. In that amendment India, however, ensured that her concurrence was necessary 'for trans-Valley uses of Gandak waters.....in 
the months of February to April only.' Yes, the Gandak treaty has more irrigation ${ }^{10}$ for Nepal than the Kosi: 12,500 ha for Nawalparasi and 34,400 ha for Parsa and Bara. But unfortunately India has never provided Nepal the stipulated quantum of water from Gandak, in particular the 850 cusecs from Don Canal for Parsa and Bara districts.

\section{iii) 1996 Treaty on Integrated Development of the Mahakali River}

World Bank's GSBA View: The third treaty between India and Nepal was the Mahakali Treaty that entered into force in 1997. The Mahakali River runs north to south along Nepal's western border with India. The Mahakali Treaty emphasized an integrated approach to water resources development, benefit sharing, and the need to revisit earlier activities and agreements based on present needs. It also included provision for the development of the Pancheshwar Dam (which remains un-built). It aimed to maximize the benefits for both countries, an approach that was absent in the Kosi and Gandaki treaties and is generally considered consistent with international good practice. But again, the treaty was met with widespread controversy in both India and Nepal.

View from Nepal: The Bank mentions that the Mahakali Treaty aims 'to maximize the benefits' for both countries and is 'generally considered consistent with international good practice.' But the Bank does not elaborate why the Pancheshwar Dam, despite its aim to complete it in 8 years, remains un-built since 1996. While the treaty does mention 'equal sharing of the Mahakali waters' to placate Nepalese ears, it does not, in the same breath, fail to stipulate 'without prejudice to their respective existing consumptive uses'. Only later did it dawn on the Nepalese that 'without prejudice' to India's existing consumptive uses meant not only the claim for the entire Sarda Canal capacity of 326 cumecs but also the flows of the Lower Sarda Canal, $160 \mathrm{~km}$ downstream. On the unutilized portion of waters (entirely Nepal's as her irrigation infrastructures are yet to be developed), Nepal's then politicians at the helm, meekly acquiesced to India's ruling '... precludes the claim, in any form, by either Party on the unutilized portion of the shares of the waters...' On equal sharing of the 6,480 MW hydropower, the story is no different. The Treaty's Letters of Exchange stipulate '....net power benefit shall be assessed on the basis of, inter alia, saving in costs to the beneficiaries as compared with the relevant alternatives available.' For Nepal the alternatives meant thermal plants (coal, oil and gas) but India has her own interpretation. It is precisely because of such obfuscation that the Pancheshwar dam remains un-built. And the Bank sanguinely wants Nepalese to believe that the Mahakali treaty is 'consistent with international good practice'.

iv) 1996 Treaty on Sharing of Ganga/Ganges Waters at Farakka

World Bank's GSBA View: India and Bangladesh entered into a number of successive agreements from 1975 through 1988. After prolonged negotiations, the two countries concluded a treaty on sharing the Ganges in 1996. The Ganges Treaty, whose provisions dictate inter alia the allocation of flows at Farakka Barrage (at the Ganges Strategic Basin Assessment IndoBangladesh border), has also raised equity concerns in some quarters. The Ganges Treaty, allocated the low dry-season flows at Farakka between India and Bangladesh, but did not specify how much water India could withdraw upstream from the Farakka Barrage, nor did it address high-flow (flood) issues.

View from Nepal: To understand the Farakka barrage issue, one needs to delve earlier than the "number of successive agreements from 1975...' As early as 1854, Sir Arthur Cotton envisaged a barrage across the Ganges to augment the Bhagirathi-Hooghly flows and flush the sediments building up at the Calcutta port. Despite Pakistani protests, India implemented Sir Cotton's plan by unilaterally constructing in 1963 the Farakka barrage on the Ganges. After completing the barrage and bypass feeder canal of 40,000 cusecs capacity in 1975 , India officially notified Bangladesh that she wanted to 'test-run' them. Bangladesh, hence, took this issue to the United Nations in 1976 arguing for continuation of the Ganges natural flows based on her 'historic right' uses. India countered that the Farakka barrage was an 'intrinsically bilateral' issue and Bangladesh should not question India's legitimate 'use of the water for its own reasonable requirements'. As expected, when issues relating to 'budding' Super Powers are concerned, the United Nation's Special Political Committee of the General Assembly issued a consensus agreement that the parties arrive at a 'fair and expeditious settlement'. It is in such a contentious background that the 1996 Treaty on the Sharing of the Ganga/Ganges Waters at Farakka took birth. Naturally 'equity concerns' in Bangladesh were bound to be raised. Such equity concerns, regarding the sharing of Teesta waters between these two countries, still resound.

Some Fundamental Questions: As part of the Ganges Strategic Basin Assessment study, the Bank has posed 10 fundamental questions stating the general perception on those questions and countering them with what the GSBA findings actually were. This article has picked up the Bank's only four Nepal-related fundamental questions and attempts to project the views as seen from Nepal:

Question 1. Is there substantial potential for upstream reservoir storage in the Himalayan headwaters of the basin?

\section{General Perception: Yes}

Much has been written about the potential for large water storage structures in the Himalaya. It is generally assumed that this potential could be harnessed through 
large multipurpose dams to produce hydropower, deliver more timely irrigation water, and regulate the extreme flows of the Ganges River.

\section{Bank's Findings: Not Really}

Although many sites are attractive for the development of multipurpose water storage infrastructure, the steep terrain and deep gorges allow surprisingly little water to be stored behind even very tall dams. Developing the full range of structures under consideration in this report would provide additional active system storage equivalent to only about 18 percent of annual average flow, which is not very significant on a basin wide scale.

View from Nepal: The Bank has very rightly cited the example 'In Egypt's flat terrain, the Aswan High Dam, with a height of 111 meters, can store 162 billion cubic meters of water, whereas the Andhi Khola Dam site on the Kali Gandaki River in Nepal, with a comparable height of 110 meters, would store only 0.9 billion cubic meters.' Yes, with waters tumbling down the world's highest peaks into the flat Ganges basin within a short stretch, 'surprisingly little water.... equivalent to only about 18 percent of the basin's annual average flow' can be stored in the Himalayan region. Yes, for such 'surprisingly little water', it is time that our policy makers be selective and seriously vet only those projects of national interests? The 600 MW Budhigandaki for dire domestic energy needs or the 3,000 MW Kosi High Dam for India's dire irrigation and flood control needs should be vetted very much by Nepal. With tens of thousands of Nepalese to be displaced from their villages in perpetuity from these fertile river valleys, the social and environmental costs on the flora and fauna would be of immense unprecedented proportions. Yet, the two countries have not so far dared to vet these issues publicly. Sadly, the only issues that hog the media's limelight are the huge energy (read for Nepal) with some flood control and very little irrigation (also read for both Nepal and India) benefits. The question that has begun to raise its head in Nepal is "Should Nepalese be submerged and displaced from their and their forefathers' homes for ever for the sole benefit of people across the border?' This is the answer the Nepalese public want from the governments of Nepal and India before anything is done on the Kosi High Dam.

Question 2. Can upstream water storage control basin wide flooding?

\section{General Perception: Yes}

Himalayan storage reservoirs are commonly seen as the answer to the flooding that plagues the Ganges plains and delta, especially in areas of Bangladesh, Bihar, and eastern Uttar Pradesh.

\section{Bank's Findings: Not Really}

Although a moderate amount of flow could be stored at the sub-basin level, this storage is unlikely to significantly reduce flooding because it is generally not the level of peak flows in major (usually embanked) tributaries that causes flooding, but rather localized rainfall, high flows in smaller tributaries, and embankment failures.

View from Nepal: The Bank categorically concludes that flood control 'using upstream storage is very limited' and goes on to state that the Kosi High Dam's 'impact on flooding would likely be modest...' Yet, after the Kosi river breached its eastern embankment in Nepal on August 18, 2008, India's Water Resources Minister, Saif Uddin Soz, is quoted ${ }^{11}$ as saying 'We have already taken decisions.... Kosi is in focus this time in particular...Our main interest is flood control and irrigation. Those are our first and second priority. If we get hydroelectricity as a by-product, it will be a bonus for us.' This means the Government of India has already decided to execute the Kosi High Dam irrespective of the findings of the World Bank's GSBA or her own Patna-based Ganga Flood Control Commission. What is enlightening for Nepal is the Bank's India-centric statement '....almost all of the major tributaries in the basin are fully embanked. Lowering flood peaks within these embanked rivers is unlikely to have a significant effect on flooding events.' This was exactly the Indian stand on flood control benefits during the Karnali Chisapani negotiation in the 1980 s, and this still is India's stand on the Pancheshwar negotiation. When Indo-centric views are uttered verbatim by the World Bank, the so called honest broker, the GSBA is bound to be perceived by Nepal as skewed.

Question 3. Can upstream water storage augment low flows downstream?

\section{General Perception: Yes}

In addition to holding back floods, these reservoirs are expected to release water stored during the wet season for use in the dry season. This release would augment low flows for ecosystems, agriculture, and other uses across the basin, especially in the dry months preceding the monsoon.

Bank's Findings: Yes, but...

In physical terms, the modeling results confirm this expectation. Low-flow augmentation could indeed be significant if all the large dams under consideration were built, approximately doubling low flows in the driest months. Storing even a minor portion of the flood flows until the dry season could significantly increase low flows especially in a very dry years....

However, the economic value of this additional low-flow augmentation is unclear because of soil water logging and low agricultural productivity in India and Bangladesh. Water is not the crucial constraint to agricultural productivity in the specific parts of the Ganges Basin that could receive additional flows...

View from Nepal: This is where the World Bank with 
the 'Yes, but....' statement has dealt the most deadly 'Et tu Brute?' blow to Nepal. This is where Nepal finds the Bank's GSBA skewed and flawed. The Bank categorically concludes 'low-flow augmentation could indeed be significant' due to upstream storages. In fact, if all the large dams (Pancheshwar, Sapta Kosi and Karnali) are built, then low flows in the dry season would 'approximately double'. But the Bank, in the same breath, hastens to qualify 'the economic value of this low-flow augmentation is unclear because of low agricultural productivity and localize water logging. Water is not seen to be the crucial constraint to agricultural productivity...' This is a deliberate attempt by the Bank to downplay the value of water. These are exactly the same arguments that India bandied on the Karnali Chisapani and Pancheshwar projects. A bad monsoon in the Indian subcontinent automatically means bad agricultural productivity. India, from British through her Republic times, invested massively in her irrigation infrastructures particularly in UP and Bihar - from the Sarda/Banbasa and Tanakpur, Ghagra/Girijapur, Saryu/ Laxmanpur to the Gandak and Kosi barrages. With such infrastructures, the Bank itself mentions that UP alone has been able to irrigate about 9 million hectares at least partially with surface waters.

Now consider the demography and poverty of the Ganges basin that the Bank itself states 'The huge population of the Basin, combined with pervasive poverty and extreme population density, mark the Ganges Basin as a unique global challenge......poverty rates in the basin approach those of Sub-Saharan Africa.' The Bank indicates that 655.5 million people (India 576.3 million, Bangladesh 50.7 million and Nepal 28.5 million) live within the Ganges basin. The population of Nepal's three bordering States of UP, Bihar and West Bengal (199.4 million, 103.7 million and 91.4 million respectively) means a staggering population of 384.5 million far exceeding that of the world's only superpower, USA. When 576 million Indians (47 percent of India's population) live in the Ganges basin, how can the Bank make the sweeping remark that 'low flow augmented' Ganges waters is not crucial to India? What economic value does the Bank really want to peg for this low-flow augmentation? From the sill level controversies over the tiny Mahali Sagar (UP/Kapilavastu border) through the sill level of the Nepal intake at Tanakpur to the Mahakali treaty's 'without prejudice to their respective existing consumptive uses' clause, water and lean season water has been India's one and only concern.

In fact, India believes ${ }^{12}$ every drop of water is equivalent to a drop of blood. This led the Government of India to launch the controversial IC Rs 5,600 Billion River Linking Project (RLP) in 2002. The 220 meter Kosi High Dam (live storage 9.4 BCM), 240 meter Karnali Chisapani (live storage 16.2 BCM) and 250 meter Pancheshwar $^{13}$ (live storage 6.6 BCM) in Nepal are the key critical players in the Himalayan component of the RLP for storing water during the wet season. During the dry season this $32.2 \mathrm{BCM}$ of water stored by submerging Nepal is envisaged to be transferred to the drier west, India's bread basket, to augment the flows of the rivers along the way. The World Bank's GSBA has studiously uttered not a single word on India's River Linking Project. It is believed this loud ominous silence on the RLP definitely emanates a message. The Bank's findings that even augmented water is not 'a critical constraint to India's agricultural productivity' means the honest broker' is hand in glove with the Government of India.

\section{Question 4. Is there substantial untapped hydropower potential in the Ganges basin?}

\section{General Perception: Yes}

The Himalayas have enormous hydropower potential. This power is seen as a source of domestic energy supplies as well as a source of export revenues for Nepal where potential supplies far outstrip potential demand. It is also seen as an important source of clean energy in a region that is experiencing high growth.

\section{Bank's Finding: Yes}

In Nepal alone, it is estimated that more than 40,000 megawatts of economically feasible potential hydropower exists in the Himalayan headwaters of the Ganges. Less than 2 percent has been developed. The suite of dams examined in this report, the largest 23 in Nepal, would have an installed capacity of about 25,00o megawatts, producing an estimated 65-70 terawatt hours of power annually (and saving up to 52,000-56,00o tons of carbon equivalent per year (very low figure-Editor). The net value of this potential hydropower is estimated at some \$5 billion annually, quite significant relative to Nepal's 2009 GDP of $\$ 12.5$ billion.

View from Nepal: For the last six decades, Nepal has been singing hoarse this hymn on untapped hydropower potential. As part of that song, with load shedding exceeding 12 hours per day in the dry season, the Nepalese government recently rolled out two reports on $10,000 \mathrm{MW}$ in 10 Years and 25,000 MW in 20 Years. It is, hence, no revelation that the Bank confirms Nepal's untapped hydropower potential. The Bank has estimated the economic value of hydropower as 'some US\$ 5 billion annually' in Nepal's 2009 GDP of US\$ 12.6 billion. This is a substantial amount indeed. But the Bank has conveniently not delved into why this substantial hydropower remains untapped in Nepal.

Take the case of the celebrated 10,800 MW Karnali Chisapani where the Bank's President McNamara together with US President Carter and British Prime Minister Callaghan were very keen to implement it. India was not happy with the Bank's benefit assessment of: power $81 \%$, irrigation $18.9 \%$ and flood control $0.1 \%$. India argued that irrigation and flood control benefits were negligible to her and only power benefit considerable. India refused to be loaded with these 
negligible benefit costs and the project collapsed. While India's ex-Foreign Secretary, Jagat Mehta, lamented 'My greatest unfulfilled ambition was not to have been able to.....come to grips on eventual power supply from Karnali...' Recently an ex-Indian diplomat ${ }^{14}$ has been quoted as saying that India has no problems with any country (read China) developing hydropower in Nepal. But he stresses that the electricity rates for sale to India would have to be palatable to her. This is the crux of the matter, India's monopoly market.

The Bank in its report is at pains to explain that India's projected power shortfall by 2017 would be 100,000 MW and the Government of India has 'repeatedly stated its interest in importing Nepal's surplus, clean hydropower.' It goes on to add that 'power exports from Nepal to India could help correct Nepal's persistent balance-of-payments deficit with India.' Such 'repeated and persistent' statements are indeed very fine on paper. But why is it not happening? Is Nepal alone to be faulted? Take the case of the Bank cited 'cross-border transmission projects are now being implemented'. Very few are aware that this long awaited $400 \mathrm{kV}$ Muzaffarpur-Dhalkebar cross border transmission line is a One-Way power traffic. That is, the present arrangement ${ }^{16}$ is meant only for importing Indian power! India is excessively paranoid about choreographing Nepal's huge hydropower' access into India's so called hungry 100,00o MW' market.

The Bank, no doubt, is hand in glove with India. Consider the Bank's following statement: 'Whereas most observers tend to focus on the installed capacity of a power plant (in megawatts) when discussing hydropower potential, it is, in fact, the actual power generation (e.g. in megawatt-hours) from the system that constitutes the economic benefits. Power generation reflects the hydrology of the river and the size of the reservoir. For example, as shown by the modeling analysis, the Kosi High Dam has an installed capacity of only 3,50o megawatts, but can produce more power than the Chisapani Dam with an installed capacity of more than 10,00o megawatts.' This is a deliberate attempt by the Bank to fool Nepal's policy makers. The simple reason for Nepal opting for higher installed capacity (Megawatts) is the higher value of peaking energy she can obtain. This is what India's GMR Energy Ltd is doing by raising the $300 \mathrm{MW}$ Upper Karnali to $900 \mathrm{MW}$ and this is what the Government of India Undertaking, Satluj Jal Vidhyut Nigam (former Nathpa Jhakri Power Corporation), has done with the 201 MW Arun III by upgrading it to 900 MW. Both GMR and Satluj have their eyes fixed on the peaking energy value that is getting more lucrative in the Indian power system. Yet, the honest broker wants Nepal to operate her hydropower on base load with lower energy value. The all underlying reason for this is that India prefers a continuous supply of water for her irrigation systems rather than in spurts (though there will be re-regulating dams) when plants are operated only for peaking purposes. This is the reason why India wants to lower the installed capacity of the 6,480 MW Pancheshwar project. And this is the reason why the India-designed Kosi High Dam has a mere 3,00o MW installed capacity. The Bank has also given non-factual data on Kosi High Dam and Karnali Chisapani energy generations. Reports ${ }^{17}$ available to Nepal show that the 10,800 MW Karnali's annual energy generation at 20,842 million units is greater than that of 3,000 MW Kosi High Dam at 15,732 million units. This is, thus, the Bank's skewed and flawed attempt to make its GSBA report as Indo-centric as possible.

\section{Final Word: Nepal's Right to say No}

Inexplicably, the World Bank's Ganges Strategic Basin Assessment has excluded the Tibetan population from the Ganges basin but has not forgotten to include Nepal's Kalapani as an Indian territory. On the four bilateral treaties in the Ganges basin, the Bank has been at pains to reflect only those views that do not rub India the other way. That is why at a recent Kathmandu consultative workshop ${ }^{18}$ on the Bank's GBSA report, the overwhelming commentators found the report too Indocentric with some not hesitating to assess it as flawed.

On the potential for upstream storages in Nepal, due to steep gorges in the mountain 'significantly little water' can be stored. The well-cited example is the 111 meter high Aswan Dam in Egypt that stores 162 billion cubic meters of water while the similarly high 110 meter Andhi Khola dam in Nepal can store a mere 0.9 billion cubic meters of water. Even the top prioritized 220 meter (as given by GSBA) high Kosi High Dam can store only 9.5 billion i.e a storage capacity of only one-sixteenth of Aswan Dam despite having a two times height. Similarly, the GSBA goes in length to describe why the potential to control floods through upstream storages in Nepal is 'very limited' and that many of the Ganges tributaries are already well embanked. India would find this palatable as she has always been downplaying the flood control benefits. But what would indeed be far more palatable to India is the GSBA finding that though upstream storages can 'double the lean season flows', the economic benefit to be derived from agriculture through augmented flows is 'currently quite low'. This, of course, is not palatable to Nepal. However, the Bank finds the potential for hydropower development and trade 'significant' and that it is 'simpler to negotiate than previously thought.' And this will be music to those groups of Nepalese who have been wailing at Nepal's 'apar khera gai rakheko pani' (enormous water going to waste).

The World Bank's clear message, for Nepal, is go full speed ahead with hydropower of 'significant trade value' and don't bother with the 'currently quite low' irrigational benefits and flood control of 'very limited' value. With such prescriptions, the multilateral institution is advocating a policy whereby India does to Nepal what Brazil did to Paraguay. In early 1970 s Brazil and Paraguay implemented the 12,600 MW Itaipu bi-national hydropower project, till recently the world's largest. Despite selling half of Itaipu power to Brazil for a quarter of a century, Paraguay still 
remains the second poorest country in Latin America. It is not the 'significant' power trade that counts. What actually counts is the Energy Rate at which that power trade is done with India. And the Bank's 'simpler to negotiate than previously thought' means that Nepal should be far more cautious than she had been 'previously' in her negotiation with India. By pushing Nepal's significant hydropower, the Bank is clearly advocating a policy whereby India, through Nepal's default, freely avail lean season water stored in submerged Nepal as, in the Bank's own opinion, agricultural productivity is currently very low and flood control very limited in India. Nepal, naturally, is very disappointed with the Bank's such Indo-centric assessment.

Are the Bank's findings really in Nepal's interests? Is this a win-win policy for Nepal? Many Nepalese believe that Nepal should not rush just because of 'significant' power trade. Nepal should wait until the 'currently quite low' irrigation and 'very limited' flood control benefits also register a rise. Nepal, in the meantime, should implement projects that will cater to her own domestic water and energy needs. Nepal, as a member of the World Bank, has every right to reject the Bank's Indo-centric GSBA report. Nepal, similarly, has every right to say NO to large projects that submerge for perpetuity vast tracts of fertile lands and villages in Nepal until their 'accrued downstream benefits' are also conceded by the World Bank to be 'significant' !

S.B. Pun is the former Managing Director of Nepal Electricity Authority (NEA) and in his closing years served as the Officer on Special Duty at the Ministry of Water Resources, Government of Nepal. He writes on energy and water issues.

Corresponding address: santapun@ntc.net.np

\section{Notes}

1. From India: Integrated Natural Resource Management Consultants of Delhi, Indian Institute of Technology of Delhi, RMSI Pvt. Ltd. Delhi, Indian Statistical Institute, International Water Resources Management Institute (IWMI) in India; from Bangladesh: Institute for Water Management Dhaka, Center for Environmental and Geographic Information Services Dhaka and from Nepal International Centre for Integrated Mountain Development (ICIMOD) Kathmandu. The report also acknowledges the inputs of Nepalese individuals like Dipak Gyawali, Ajaya Dixit, Mandira Shrestha, Shyam Ranjitkar and Rajib Upadhya.

2. It is reported that Bangladeshis, who worked on this Model, were surprised that the model the World Bank selected for Nepal was not the most appropriate one.

3. Actually, three riparians with China's Tibet.

4. The Bank notified China about the 201 MW Arun III project on November 14, 1993 and the Government of China gave its 'no objection' concurrence on January 14, 1994. - World Bank's Staff Appraisal Report on Arun III Hydroelectric Project dated August 29, 1994. The Bank also used this notification on the classic Babai Irrigation Project that was aborted due to Indian objections.

5. Rasgotra, MK. 2004. Discussion II, India-Nepal Relations: The Challenge Ahead. Observer Research Foundation. New Delhi. Rupa \& Co.

6. Verghese, BG. 1990. Waters of Hope. Centre for Policy Research. New Delhi. Oxford \& IBH Publishing

7. Malla, SK. 1995. Case Study of Kosi and Gandak Projects. Thapa, BB \& Pradhan, BB. Water Resources Development. Delhi. Konark Publishers.

8. Nepal gets another 13,800 ha through pumping from the western canal. The 66,000 ha upstream is not from the Kosi barrage.

9. Ambassador Dev Mukherjee at Face to Face Program of Reporters' Club, May 26, 2001 Kathmandu. Partnership in Economic Development. BP Koirala India-Nepal Foundation. Embassy of India, Lainchour, Kathmandu.

10. World Bank's Project Completion Report of Narayani Zone Irrigation Development Stage II Project, July 1, 1991.

11. Nepali Times, September 19-25, 2008 \# 418

12. As told by Indian High Commissioner to Bangladesh, Muchkund Dubey, to Nepalese ambassador, Harka Bahadur Thapa, at Dhaka in the late 1970s during the height of Indo-Bangladesh Farakka barrage controversy.

13. The heights of these three dams are those as given in the Bank's GSBA report. One does not know where the Bank availed them. The height of Kosi High Dam according to Ministry of Irrigation/GOI (December 1983) is 269 meters, that of Karnali Chisapani according to Ministry of Water Resources/ HMGN (December 1989) is 270 meters and that of Pancheshwar Dam (Detailed Project Report, MOWR/HMGN, November, 1995) is 315 meters.

14. Verghese, BG. 1990. Waters of Hope. Centre for Policy Research. New Delhi. Oxford \& IBH Publishing

15. Ex-ambassador and Foreign Secretary Shyam Saran to Kathmandu Post January 14, 2013.

16. The argument for this one way traffic is for importing 150 MW into Nepal. But 'if the spirit was willing' then this cross-border transmission line could easily have been provisioned for a two-way 150 MW power trade. Many foreign developers (read non-Indians) were keenly banking on this key $400 \mathrm{Kv}$ cross-border transmission line to be a-two way traffic.

17. Karnali (Chisapani) Multipurpose Project, Feasibility Study, December 1989, HMGN/ Ministry of Water Resources. Comprehensive Plan of Flood Control for the Kosi Sub-Basin, December 1983, Ganga Flood Control Commission, GOI/Ministry of Irrigation.

18. Organized by Jalsrot Vikash Sanstha at Himalaya Hotel on July 20, 2012. The Chief Guest was Karna Dhoj Adhikari who incidentally was Chief Engineer/ Irrigation Department, Secretary/Water Resources Ministry, Chief Secretary and Nepal's Ambassador to India as well.

HYDRO NEPAL ｜ ISSUE N0.12 ｜ JANUARY, 2013 